\title{
Sciendo
}

\section{Falsification of the Theory of Legal Rules and Legal Standards of Ronald Dworkin Using the Methodological Foundations of the Theory of Law and Morality of Leon Petrażycki}

\author{
Krzysztof Majczyk \\ The Aristotle Foundation, Poland \\ Jagiellonian University in Cracow, Poland \\ e-mail: krzysztof.majczyk@gmail.com
}

\begin{abstract}
:
Efficient thinking is the foundation of efficient operation. The correct definition of concepts, especially the basic ones for a given field, in order to reach the truth, is a condition for the development of science and its social utility. The Petrażycki's research methodology of law is a thoroughly modern method, as it enables effective examination of the accuracy of contemporary legal theories created after Petrażycki's input.
\end{abstract}

A model contemporary theory susceptible to an examination through the research methodology of law by Petrażycki is the normative theory of legal rules and non-legal standards by Dworkin. For this purpose some falsifications will be subject, i.e. selected ad hoc among many others, two important theories of normative law theory Dworkin. The first one is the thesis classifying legal norms into two groups of norms, namely legal rules and non-legal standards. The second one is a thesis about the existence of who are capable of discovering and issuing lawful and, at the same time, fair (just) court decisions, which are also the only ones for resolving particular court disputes.

Unfortunately, owing to the seemingly cognitive research methodology of Petrażycki, both Dworkin's deformed division of legal norms as well as Dworkin's Hercules judges - cannot stand the test of authenticity. Due to the Petrażycki's methodology, the legal-normative theory of Dworkin does not lose an innovative outlook on the existence of social norms, which are being discovered by judges in the jurisprudence, indifferently to the doubts over their proper classification (be it non-legal standards or, perhaps, outright standards supplementing statutory and sub-statutory legal regulations). Moreover, Dworkin's theory is placed between naive theories, regardless of whether they are considered realistically naive theories (towards the Hercules judges) or nihilistically naive theories (when it comes to the existence of the only judgments in the given court cases which are also the just ones.) A few random reflections on the well-known work of Dworkin with the help of Petrażycki's methodology serve to provide a new perspective on the contemporary legal normativity.

Keywords: methodology, falsification of theory, theory of rules and standards of Dworkin. 
If the language is not correct, Then the speech does not mean what it is supposed to mean. If speech does not mean what it is supposed to mean, what is to be done, will not be done, and then morality and all art will be corrupted and justice will go astray and everyone will be in a state of confusion.

[Unknown author]

\section{Introduction}

It is a truism to postulate a search for a philosophical basis of decision making for the societies' welfare. There are two concepts which are covered, these are ideas and society, which are positioned in a variety of extremely different types of relationship towards each other. Widely considered globalization requires an improvement of interpersonal communication and nothing seems to amplify a quality of a conversation as intensely as interdisciplinary meetings.

Efficient thinking is a foundation of an efficient operation. Defining concepts correctly, especially the ones which are basic in a given field, in order to reach the truth conditions the development of science and its social utility. Paradoxically, the law exploratory methodology by Leon Petrażycki is an entirely modern method, as it enables an effective investigation of the truth of contemporary theories of law. These were created after the construction of the exploratory methodology by Petrażycki, while it heavily draws on the Aristotelian dialectic [1].

An ideal contemporary theory prone to research through the law exploratory methodology by Petrażycki is the normative theory of legal rules and non-legal standards of Dworkin. For this purpose, two important theories of Dworkin's normative law will undergo a process of falsification. They were selected ad hoc, among many others. The first thesis divides legal norms into two groups, namely legal rules and non-legal standards. The other one focuses on the existence of Hercules judges who are capable of discovering and issuing lawful, and at the same time just court decisions, which are also the only possible decisions for resolving particular court disputes.

Unfortunately, owing to the seemingly cognitive research methodology of Petrażycki, both Dworkin's deformed division of legal norms as well as Dworkin's Hercules judges - cannot stand the test of authenticity. Due to the Petrażycki's methodology, the legal-normative theory of Dworkin does not lose an innovative outlook on the existence of social norms, which are being discovered by judges in the jurisprudence, indifferently to the doubts over their proper classification (be it non-legal standards or, perhaps, outright standards supplementing statutory and sub-statutory legal regulations). Moreover, Dworkin's theory is placed between naive theories, regardless of whether they are considered realistically naive theories (towards the Hercules judges) or nihilistically naive theories (when it comes to the existence of the only judgments in the given court cases which are also the just ones.)

A few cursory reflections on the well-known work of Dworkin with the use of Petrażycki's methodology serve as an opening to a new perspective on the contemporary legal normativity.

\section{Petrażycki’s Methodological Assumptions about Law and Morality}

Under the reign of the legal-historical school and the upcoming triumph of juridical positivism, as Petrażycki used to call it - practical-dogmatic jurisprudence (mainly Ihering), the philosopher dared to return to the ancient roots of jurisprudence based on the natural law, enriching successful polemics with the schools. He did it by introducing research methodology which stretches up to the topical Aristotelian traditions [5, p. 11]. In 1908, opposing to "selfish practical interests" in the jurisprudence, which "poison the social life and social psyche", he had already foreseen their 
"devastating influence on legislative and state policy in general and on justice" [5, p. 12]. ${ }^{1}$

Petrażycki's work presents his lively opposition towards individual and collective, national egoism. This attitude of his is incredibly valid at all times. However, these deficiencies in managerial principles and ideals of the jurisprudence were approached by Petrażycki in a methodological manner. He emphasized a need which has not proposed yet by the school of the natural law. The need to establish and develop a new legal discipline "which would be based on premises, recognized by scientific considerations as a sound basis for resolving political and legal issues, and using scientifically-conscious methods of thinking would built a system of scientifically justified claims of legal policy."

In terms of strategy Petrażycki was a law visionary. He defined law as psychological phenomena which could be influenced by the jurisprudence through

"bringing up the social psyche" and, at the same time, used logic with finesse as a cognitive methodology: The basic method of political and legal thinking is psychological deduction - conclusions about mental effects drawn from particular psychological premises - motivational and educational, which should trigger action of certain rules and legal institutions, or when it comes to legislative measures that may elicit some desirable psychological consequences - motivational and educational. While it is possible in certain areas and boundaries to also apply an inductive method, next to psychological deduction, then, logically, the legal policy should use as well this method to check the validity of deductive applications [5, p. 11].

\section{Falsifiablity of Dworkin's Thesis about the Existence of Legal Rules and Non-Legal Standards Based on the Methodology of Petrażycki}

The psychological method of perceiving Petrażycki's legal phenomena enables an exposure of ontological errors made by Dworkin while formulating his normative theory. By comparing the long, exorbitantly complicated and, at the same time, the most important in the $20^{\text {th }}$ century legal dispute about the notion of law (Hart-Dworkin) to Petrażycki's methodology, it can be concluded this methodology enables cutting, like Occam's razor, through many arid digressions of that time.

From all of the fundamental theses of the legal-normative theory of Dworkin subjected to the test of truth, the first one is the thesis about the existence of a dichotomous division of legal norms into legal rules and non-legal standards.

This is a thesis refutable by Petrażycki's methodology. Petrażycki consequently applies Aristotle's vision of the world to law, using both analytical and dialectical syllogisms alternatively. The philosopher draws from the Aristotelian sophisms, precisely about the error of circular reasoning (a vicious circle - idem per idem) [1, p. 302].

The aforementioned affliction of lawyers was commonly known in the times of Petrażycki. For that reason Petrażycki quotes the definition of law by a well-known German theoretician named Biering: "Law in the legal sense is ...". Petrażycki vigorously points out the mistakes of philosophers of law, caused by the usage of professional terminology in the attempts to address the questions about what law is:

What they recognize as law, as 'right undoubtedly' is all this, and only this, what they got used to call 'law' as lawyers. Everything else from their point of view comprises non-law, 'undoubtedly non-law'. Whereas different usage of the word "law" in a colloquial language usually is not recognized by lawyers, nor do they take it into account [... In reality, one terminological custom is opposed to the other which is incompatible with it, and it is groundless to claim that the colloquial application of the word "law" is incorrect. If a lawyer perceives something as an actual law and this phenomenon is what he got used to describe as a law and, if the thing that is perceived right by non-lawyers he sees not as law but as something incorrectly defined as such, 
then such attitude cannot be justified but it can only be explained as peculiar mental circumstance [5, p. 90],

therefore, sophism, a faulty proof of an idea, a false meaning of a thought.

Dworkin created a dichotomous normative theory, the theory of legal rules and non-legal standards, in which he did not recognize the second type of norms as worthy of a status of the legal norms. This status was given by him only to the non-legal social rules with legal consequences. Yet, it still might be difficult to understand why Dworkin did not dare to show any appreciation towards them in legal terms, to classify them as legal norms that complement legal rules.

On the whole, a question arises - was it a case of disrespect toward the natural law common among current lawyers, even those outstanding ones, that took precedence over Dworkin, a wellknown philosopher of law?

Moreover, it is also known and will be proved below that Hercules judges do not actually exist, despite Dworkin's belief. One can explicitly say Dworkin consciously used the fictional idea of the Hercules judges. For this reason, such fiction was necessary to justify yet another fiction, specifically, the monistic, idealistic fiction of the existence of a sole, lawful and just judicial decision in a given litigation between disputing parties. Dworkin's efforts in the normative field, including recognition of legal rules as the only legal norms, resulted from his psychological desire to justify the existence of a hierarchical closed empire of law, in which the judges are emperors, princes and dukes [2].

Dworkin did not avoid particularism in his normative-legal concept. By making use of his works, he aimed, perhaps subconsciously, at legitimization of an enormous judicial power in his homeland, the United States of America - a multicultural empire. He sought both - such norms and such power - that would order the reality in which he lived and created. The reality in which he lived and created seemed unstructured to him, so this might be why he was looking for such norms and such jurisdiction that would help to put the aforementioned reality in order. He indicated dichotomous legal normativity and the power of judges who are in his opinion entitled to discover and apply extra-legal standards in certain legal situations, as well as to pass contra legem sentences. However, this work was doomed to fail, consequently with Dworkin admitting it toward the end of his life [3].

Petrażycki, on the other hand, repeatedly presented the reality as a pluralistic world and, at the same time, a world wide open. Unfortunately, when comparing Dworkin's vision of the world with the open and, eventually, the internally conflicted world of diversified social norms, it is a lot easier to take on, in statu nascendi, the truth about the existence, which brings much more cognitive and adaptive difficulties. However, Petrażycki did not leave the idea hanging but indicated an urgency to work on the law policy as on a crucial issue. Specifically, the necessity to improve on "legal principles and on managerial ideals", while avoiding "shallow practical utilitarian directions" in the indecent meaning of this word, deprived of the principles of general ideas and ideals [5, $\mathrm{p}$. 12].

Dworkin allowed himself, following to the proverb "the end justifies the means," to accept successive scientific fictions. Firstly, when it comes to the legal norms entitled to be present in the sentences of the court judgments, Dworkin distinguished only the existence of legal rules as such. Next, the second fiction Dworkin approved of were the Hercules judges. Finally, he recognized only the existence of sole, idealistic court judgements in specific litigations. On the other hand, Dworkin turned to non-statutory, or rather, precedented judges' oeuvre as if they barely were extralegal, social standards. By doing so, Dworkin was not preservative. It is because he discovered yet another legal norms used parallelly with legal norms commonly known, however he refrained from calling it what they actually were, being under the influence of profession-oriented habits which were, in fact, described by Petrażycki.

Unfortunately, a different creative decision would have forced Dworkin to reformulate his lifework which was a closed, hierarchical, monistic, philosophical normative system, which, in his view, should be used by "priests of the system," in other words - by the Hercules judges. Opening 
his work to the second type of legal norms competing with legal rules would push Dworkin to broaden his conception of the previously closed normative system and to reveal the pluralism of social norms that compete successfully with legal rules, that is with the main legal norms in the ruling over judiciary practice of judicial and non-judicial authorities.

\section{Falsification of the Dworkin's Thesis about the Existence of Hercules Judges on the Basis of Petrażycki's Methodology}

The second of the fundamental theories of normative law Dworkin subjected to the test of truth is the thesis about the existence of Hercules judge capable of discovering and applying lawful and at the same time fair and, importantly, the only, ideal sentences.

By paraphrasing Petrażycki's vocabulary one can say Dworkin, experiencing legal-focused emotions while creating the theory, has been deluded to say the least. His delusion was based on perceiving the judges as if they have supernatural capacities to solve human disputes. In fact, what also has to be verbalized is that Dworkin's judges do not exist.

In accordance with the methodology of Petrażycki, Hercules judges existed only in Dworkin's psyche and his works, and after his death they remain only on the pages of his Opus Magnum titled “Taking Rights Seriously." Thus, the fundamental premise of Dworkin's normative theory presenting judges as capable of making appropriate decisions in court disputes is an ontological error regarding the condition of judges when considered in terms of Petrażycki's research methodology. These judges, prima facie people are therefore rational beings, but because of free will, prone to mistakes too. Aristotle used to say in his famous sylogism about Socrates that he, indeed, is a man and every man is mortal, hence Socrates is mortal as well. From an ontological point of view the matter of the judges looks similar: each judge is a man, not a god or a demigod (a hero), each man is fallible, therefore each judge is fallible too.

In the research methodology of Petrażycki, the fundamental premise of the Dworkin's normative theory on the existence of divine judges is as valuable as the moral epithet. It amounts to a conventional "dear" or "loved" etc. Furthermore, accordingly with Petrażycki's methodology, it is logical to assume that moral, or even legal duty of the Dworkin's judges conception is only Dworkin's imagery while creating normative law theory. Especially, that these judges are meant to adjudicate according to the highest moral standards, or with the best possible knowledge and practice. Potentially, even one hundred years ago Dworkin's aforementioned imagery would have been called by Petrażycki an internal legal experience.

Riposting to the accounts of psychic experiences, the creator of the theory of legal rules and non-legal standards on judges' judgments regarding the actual behavior of judges ruling in court disputes can be firmly stated after Petrażycki that "a lawyer will make a mistake if he starts looking for this legal phenomenon somewhere in space over people or between them, in the "social environment" or else, because in this case the legal phenomenon occurs "in his own mind" - in his or her own psyche and nowhere else" [5, p. 51]. Therefore, there is a relationship between them, most probably a psychological relationship, certainly a phraseological relationship, somewhat actual relationship, but there is no logical connection, but an optical illusion, resulting from the essence and composition of legal experiences discovered by Petrażycki.

Phenomenal methodological remarks of Petrazycki should be definitely considered as referring both to the rhetorical figure of Hercules judge created by Dworkin, and to many other currently known, significant philosophical theories of law. Petrażycki claimed that

Doctrines of lawyers and philosophers about law, its elements, variations, etc., give the image of such a pursuit of delusions, of constructing things that do not exist in a more or less ingenious and "deep" way, using various means, such as metaphysical hypotheses (an overman judge, a hero) or mystical, various unconscious stretches or even conscious recognition of unreal things as existing, with reference to the fact that without fiction, the issue cannot be solved, etc. With the time passing, theories become 
not only more and more incompatible with each other, full of contradictions, but also increasingly unclear, intricate and artificial [5, p. 53].

Giving scientific weight to folk wisdom and widely available knowledge is the success of sobriety of Petrażycki's mind. The same goes with the possibility of uncloaking this kind of false theories which even happened to be called "naive creationist theories" by Petrażycki himself. Petrażycki enables passing a cognitive judgment on the topic of Dworkin's Hercules judges seen as a hollow (nihilist) theory, similar to the thesis that "the servant is in the hallway", while he actually might be somewhere else; for example, in the kitchen [5, p. 53].

Owing to the research methodology of Petrażycki's law, the falsification of the logical value of Dworkin's thesis about the existence of Hercules judges does not encounter any research difficulties.

In compliance with Petrażycki's methodology, the theory about the existence of Hercules judges is a realistically naive theory. In Petrażycki's view Dworkin proposed an erroneous solution. Dworkin recognised an actual, existing object (Petrazycki's servant versus Dworkin's judge), however found in an invalid sphere (in the Petrazycki's hall) as a sought-after thing, which really has a completely different nature and is located in a completely different sphere (in the court itself, or in Dworkin's mental experience and not in the real world).

\section{First Summary - A Few Words}

With an increasing difficulty comes the act of handing over achievements by scholars coming from narrow scientific specializations. Nowadays, shutting down of specialization makes both the scientific interdisciplinary communication and, what is worse, communication with the society, impossible. Petrażycki presents some simple diagnostic methods of those phenomena by subjecting some randomly chosen Dworkin's theses to his research methodology. Moreover, he reveals the fresh outlook on the Polish law and lawyers by drawing from the Aristotelian work.

\section{Repackaged Summary - the General Criticism of the Legal Theory of Petrażycki}

In all fairness to scientific reliability, a shortened summary of pros and cons of Petrażycki's legal theory has to be made, not only through confrontation with Dworkin's ontology. For the contemporary scientific needs the general assessment of the theory is not clear-cut. Also, under no circumstances does it convince as strongly as it was articulately used above to falsify Dworkin's theory.

On the one hand, undoubtedly, Petrażycki's legal emotivism influences a deeper understanding of substance of law, along with its vocabulary and interpretations of will incentives, but more importantly with discovering emotions in psychological and legal categories. The legal emotivism is even of a higher value than other, mainly patchy, legal-tenet treatises by the former and current law positivists. It also yields subjectivist theories of legal behaviours, which credibly affect in-depth understanding of basic, individual legal acts, such as will incentives, will, motives, guilt, damage, legal capacity, commitment, entitlement or legal relations. They influence the legal awareness and a sum of other crucial elements for the application and interpretation of the substantive civil law, as well as for the broadly understood legal interpretation.

On the other hand, the emotive legal theory of Petrażycki cannot be analyzed only on a basis of a legal theory, especially excluding the civil law, and only with connection to an empirical context. The memory of the ethically tragic experiences of mankind is vital for this matter. The emotivist theory needs to be looked at in the light of the great totalitarianism of the $20^{\text {th }}$ century, including the pre-war, Trotsky-Lenin Russian Bolshevism, Italian and Spanish fascism, German Hitlerism, post-war Russian Stalinism and up to the contemporary nihilist, anarchist or ethically relativist, liberal Western and Eastern democracies.

It should be remembered that Petrażycki's jurisprudential theory is a philosophical and legal 
theory from the late $19^{\text {th }}$ century, a theory created in the monarchic, despotic, tsarist, yet democratizing Russia. However, considering it more broadly, Europe of that time was a completely different ethical, legal and political reality, opposing to current Russia, Central and Eastern Europe. In addition, the legal theory of Petrażycki, at least in Poland, never had a chance to be a dominant philosophical theory, precisely because of the reign of the $20^{\text {th }}$ century totalitarian regimes. These days it also is not lucky to exist among wide circles of philosophers of Polish or Russian law because it found supporters only among a few students who managed to survive the abovementioned totalitarianism. Throughout the $20^{\text {th }}$ century the theory in Polish legal culture vegetated in the scientific underground, under the overwhelming influence of legal positivism and then under the Marxist sciences about the state and law.

Furthermore, Petrażycki, as a $19^{\text {th }}$ century European rationalist favored the Enlightenment ideals of rationality power. His scientific credo was based on anthropocentric ideals of progress, thus it rejected theocentrism, the Christian paradigm of seeking truth, justice, freedom and other ethical values in God. As a result, Petrażycki, as an ontological non-cognitivist perpetrated subjectivist descriptions and assessments of the existence, permanence and meaning of non-legal, normative, social systems (which are religion and morality) in the name of ostensible ethical values, such as i.e. efficacy. He created an unjustified hypothesis about a hierarchy of normative social systems, in other words - the hypothesis about the normative primacy of the law over morality involved in implementing the society's idea of "universal kindness of all people." Such hypothesis could only get epistemological approval, however it is not possible to maintain it, either in the ontological or in the axiological sense.

A dialectical doubt arises - can we comprehend the law while using the original, even nowadays, emotivist legal theory, nevertheless created by the $19^{\text {th }}$ century law theorist Petrazycki, strongly embedded mentally in the legal system of the declining in that time, pre-revolutionary, despotic Russian empire?

Therefore, the question has to be answered of whether such a theory, even partially, and to which extent enables real reforms of modern, $21^{\text {st }}$ century, multicentric, pluralistic, multi-system law, including non-judicial and extrajudicial law, and in particular contemporary Polish law. For this reason, there is scientific need of, from one side, to continually use methodological legal techniques directly derived from the ancient technique of Petrażycki - especially from the output of Aristotelian dialectics - and from the other side - the need of, at least, an ethical criticism of Petrazycki's legal pluralism. 


\section{References}

1. Aristotle, Topics. On Sophistic evidence, transl. by K. Leśniak, Warszawa: PWN, 1978.

2. Dworkin, R. Empire of law, transl. by J. Winczorek and P. Kamela, Wolters Kluwer Poland, 2006.

3. Dworkin, R. Justice from Hedgehogs, London: Harvard University Press, 2011.

4. Dworkin, R. Taking Rights Seriously, Cambridge, Mass.: Harvard University Press, 1977.

5. Petrażycki, L. Introduction to the science of law and morality, Warszawa: PWN, 1959.

6. Petrażycki, L. Lehre vom Einkommen, Berlin, 1895.

\section{Notes}

1. The motto for the revival of the natural law Petrażycki included in [6, p. 579] already in 1895. and the first edition of the Introduction took place in 1908, so just before the horror of the First World War and the Bolshevik Revolution and then the rise of fascism in Germany, Austria, Spain and Italy.

4. [5, p. 89], footnote No. 1 in which he quotes the work of Biering, Juristische Prinzipienlehre I, p. 19. 